\title{
Index to Volume 69
}

Ackerman, D., and Breen, A. Infrastructure Development Accelerates Range Expansion of Trembling Aspen (Populus tremuloides, Salicaceae) into the Arctic. 69(2):130-136.

Bacon, C. (See Smultea, M.A.)

Ban, N.C. (See Tyson, W.)

Barr, W. (Book Review) Franklin's Lost Ship: The Historic Discovery of H.M.S. Erebus, by John Geiger and Alanna Mitchell. 69(1):108-109.

Bennett, J. (Book Review) Ukkusiksalik: The People's Story, by David F. Pelly. 69(2):205-206.

Bennike, O. (See Outridge, P.M.)

Boguski, D.A. (See Harris, L.N.)

Breen, A. (See Ackerman, D.)

Breton-Honeyman, K., Furgal, C.M., and Hammill, M.O. Systematic Review and Critique of the Contributions of Traditional Ecological Knowledge of Beluga Whales in the Marine Mammal Literature. 69(1):37-46.

Brooks-Cleator, L.A., and Giles, A.R. Physical Activity Policy for Older Adults in the Northwest Territories, Canada: Gaps and Opportunities for Gains. 69(2):169-176.

Brown, C. (See Wenzel, G.W.)

Brucker, L. (See Sokolov, A.A.)

Brueggeman, J. (See Smultea, M.A.)

Campbell, A. (Book Review) Made in Nunavut: An Experiment in Decentralized Government, by Jack Hicks and Graham White. 69(4):434-435.

Clarke, J.T., Kennedy, A.S., and Ferguson, M.C. Bowhead and Gray Whale Distributions, Sighting Rates, and Habitat Associations in the Eastern Chukchi Sea, Summer and Fall 2009-15, with a Retrospective Comparison to 1982-91. 69(4):359-377.

Courtney, M.B., Scanlon, B.S., Rikardsen, A.H., and Seitz, A.C. Utility of Pop-Up Satellite Archival Tags to Study the Summer Dispersal and Habitat Occupancy of Dolly Varden in Arctic Alaska. 69(2):137-146.

Craig, E.H. (See Craig, T.)

Craig, T., and Craig, E.H. Changes in Diurnal Cliff-Nesting Raptor Occurrence on the Ungalik River in Western Alaska: 1977, 1979, and 2008. 69(3):225-230.

Daradich, A. (See Tsuji, L.J.S.)

Davis, S.E. (See Maftei, M.)

Dawson, J. (See Mussells, O.)

Dolan, J. (See Wenzel, G.W.)

Dorais, L.-J. (Book Review) Utkuhikšalingmiut Uqauhiitigut Uqauhiliurut. Dictionary of Utkuhiksalingmiut Inuktitut Postbase Suffixes, by Jean L. Briggs, Alana Johns and Conor Cook. 69(4):435-436.

Douglas, M. (See Mitchell, W.T.)

Dove, C.J., and Wickler, S. Identification of Bird Species Used to Make a Viking Age Feather Pillow. 69(1):29-36.

Ehrich, D. (See Sokolov, A.A.)

Fall, J.A. Regional Patterns of Fish and Wildlife Harvests in Contemporary Alaska. 69(1):47-64.
Ferguson, M.C. (See Clarke, J.T.)

Fertl, D. (See Smultea, M.A.)

Flint, P.L., Reed, J.A., Lacroix, D.L., and Lanctot, R.B. Habitat Use and Foraging Patterns of Molting Male Long-tailed Ducks in Lagoons of the Central Beaufort Sea, Alaska. 69(1):19-28.

Forbes, V. (See Ledger, P.M.)

Franke, A., Lamarre, V., and Hedlin, E. Rapid Nestling Mortality in Arctic Peregrine Falcons Due to the Biting Effects of Black Flies. 69(3):281-285.

Friesen, T.M., and Norman, L.E.Y. The Pembroke Site: Thule Inuit Migrants on Southern Victoria Island. 69(1):1-18.

Frisch, T. (Obituary) Keith Charles Arnold (1931-2014). 69(2):208-209.

Frisch, T., and Schmidt, M. (Obituary) George Donald Hobson (1923-2015). 69(1):114-115.

Furgal, C.M. (See Breton-Honeyman, K.)

Gallagher, C.P. (See Harris, L.N.)

George, J.C. (See Von Duyke, A.L.)

Giles, A.R. (See Brooks-Cleator, L.A.)

Gillispie, T.E. (See Younie, A.M.)

Givens, G.H. (See Von Duyke, A.L.)

Gomez, N. (See Tsuji, L.J.S.)

Goodsite, M.E. (See Outridge, P.M.)

Green, G.A. (See Smultea, M.A.)

Greenberg, J. (See Guettabi, M.)

Griffiths, F. (Book Review) Lock, Stock and Icebergs: A History of Canada's Arctic Maritime Sovereignty, by Adam Lajeunesse. 69(3):319-320.

Guettabi, M., Greenberg, J., Little, J., and Joly, K. Evaluating Potential Economic Effects of an Industrial Road on Subsistence in North-Central Alaska. 69(3):305-317.

Gust, J.R. (See Wilson, R.E.)

Hamilton, P.B. (See Mitchell, W.T.)

Hammill, M.O. (See Breton-Honeyman, K.)

Harris, L.N., Boguski, D.A., Gallagher, C.P., and Howland, K.L. Genetic Stock Identification and Relative Contribution of Arctic Char (Salvelinus alpinus) from the Hornaday and Brock Rivers to Subsistence Fisheries in Darnley Bay, Northwest Territories. 69(3):231-245.

Hawkins, A.D. (See Streever, B.)

Hay, C. (See Tsuji, L.J.S.)

Hedlin, E. (See Franke, A.)

Howell, S. (See Mussells, O.)

Howland, K.L. (See Harris, L.N.)

Huntington, H.P. (Book Review) Fierce Climate, Sacred Ground: An Ethnography of Climate Change in Shishmaref, Alaska, by Elizabeth Marino. 69(1):110-111.

Ims, R.A. (See Sokolov, A.A.)

Joly, K. (See Guettabi, M.)

Kennedy, A.S. (See Clarke, J.T.)

Kim, K.H. (See Streever, B.)

Kinnear, L. (See Ogden, A.E.) 
Kissling, M.L., and Lewis, S.B. Nesting Activity of Kittlitz's Murrelet in the Kakagrak Hills, Northwestern Alaska. 69(3):246-252.

Knecht, R.A. (See Ledger, P.M.)

Lacroix, D.L. (See Flint, P.L.)

Lamarre, V. (See Franke, A.)

Lanctot, R.B. (See Flint, P.L.)

Landriault, M. Public Opinion on Canadian Arctic Sovereignty and Security. 69(2):160-168.

Lantz, T.C. (See Tyson, W.)

Ledger, P.M., Forbes, V., Masson-MacLean, E., and Knecht, R.A. Dating and Digging Stratified Archaeology in Circumpolar North America: A View from Nunalleq, a Thule-Era Site in Southwestern Alaska. 69(4):378-390.

Lewis, S.B. (See Kissling, M.L.)

Little, J. (See Guettabi, M.)

MacDonald, J. (See Usher, P.J.)

Maftei, M., Davis, S.E., and Mallory, M.L. Observations of Heterospecific Courtship Behaviour in an Isolated Population of Ross's Gulls (Rhodostethia rosea). 69(4):341-345.

Majchrzak, Y. (InfoNorth) The Role of Food in the Snowshoe Hare-Canada Lynx Cycle. 69(4):450-453.

Mallory, M.L. (See Maftei, M.)

Masson-MacLean, E. (See Ledger, P.M.)

McGoogan, K. (Book Review) Discovering the North-West Passage: The Four-Year Arctic Odyssey of H.M.S. Investigator and the McClure Expedition, by Glenn M. Stein. 69(1):109-110.

Mitchell, W.T., Rybczynski, N., Schröder-Adams, C., Hamilton, P.B., Smith, R., and Douglas, M. Stratigraphic and Paleoenvironmental Reconstruction of a Mid-Pliocene Fossil Site in the High Arctic (Ellesmere Island, Nunavut): Evidence of an Ancient Peatland with Beaver Activity. 69(2):185-204.

Mitrovica, J.X. (See Tsuji, L.J.S.)

Murphy, R.W. (See Wong, P.B.Y.)

Murray, R.W. (Book Review) Future Security of the Global Arctic: State Policy, Economic Security and Climate, edited by Lassi Heininen. 69(4):437-438.

Mussells, O., Dawson, J., and Howell, S. Using RADARSAT to Identify Sea Ice Ridges and their Implications for Shipping in Canada's Hudson Strait. 69(4):421-433.

Norman, L.E.Y. (See Friesen, T.M.)

Norton, D.W. (Book Review) Lost: Unsolved Mysteries of Canadian Aviation, by Shirlee Smith Matheson. 69(3):318-319.

Ogden, A.E., Schmidt, M., Van Dijken, B., and Kinnear, L. (InfoNorth) Science in the Yukon: Advancing a Vision for Evidence-based Decision Making. 69(2):210-221.

Outridge, P.M., Goodsite, M.E., Bennike, O., Rausch, N., and Shotyk, W. Seabird Transfer of Nutrients and Trace Elements from the North Water Polynya to Land during the MidHolocene Warm Period, Carey Islands, Northwest Greenland. 69(3):253-265.
Panchen, Z. (InfoNorth) Impact of Climate Change on Flowering and Fruiting Times of Nunavut Arctic Plants. 69(4):444-449.

Peric, S. (InfoNorth) The Dynamic North: Northern Climate Change from an Anthropological Perspective. 69(3):325-329.

Petersen, M.R. (See Wilson, R.E.)

Popper, A.N. (See Streever, B.)

Quinney, A. (InfoNorth). Polar Voices: Relaying the Science and Story of Polar Climate Change. 69(1):116-117.

Raborn, S.W. (See Streever, B.)

Rausch, N. (See Outridge, P.M.)

Ready, E. Challenges in the Assessment of Inuit Food Security. 69(3):266-280.

Reed, J.A. (See Flint, P.L.)

Ricker, K. (Book Review) It's a Dog's Life in Antarctica: Exploring the Transantarctic Mountains by Dog Sledge 1960-1962 and Beyond, by Peter Otway. 69(3):321-323.

Rikardsen, A.H. (See Courtney, M.B.)

Robertson, F. (See Smultea, M.A.)

Rowlett, R.A. (See Smultea, M.A.)

Rybczynski, N. (See Mitchell, W.T.)

Scanlon, B.S. (See Courtney, M.B.)

Schledermann, P. (Book Review) Baffin Island: Field Research and High Arctic Adventure, 1961-1967, by Jack D. Ives. 69(4):438-439.

Schmidt, M. (See Frisch, T.)

—_— (See Ogden, A.E.)

Schröder-Adams, C. (See Mitchell, W.T.)

Seitz, A.C. (See Courtney, M.B.)

Sformo, T. (See Von Duyke, A.L.)

Sheffield, G. (See Von Duyke, A.L.)

Shotyk, W. (See Outridge, P.M.)

Smith, R. (See Mitchell, W.T.)

Smultea, M.A., Brueggeman, J., Robertson, F., Fertl, D., Bacon, C., Rowlett, R.A., and Green, G.A. Polar Bear (Ursus maritimus) Behavior near Icebreaker Operations in the Chukchi Sea, 1991. 69(2):177-184.

Sokolov, A.A., Sokolova, N.A., Ims, R.A., Brucker, L., and Ehrich, D. Emergent Rainy Winter Warm Spells May Promote Boreal Predator Expansion into the Arctic. 69(2):121-129.

Sokolova, N.A. (See Sokolov, A.A.)

Stimmelmayr, R. (See Von Duyke, A.L.)

Streever, B., Raborn, S.W., Kim, K.H., Hawkins, A.D., and Popper, A.N. Changes in Fish Catch Rates in the Presence of Air Gun Sounds in Prudhoe Bay, Alaska. 69(4):346-358.

Suydam, R. (See Von Duyke, A.L.)

Talbot, S.L. (See Wilson, R.E.)

Thorne, R. (See Woo, M.-K.)

Tsuji, L.J.S., Daradich, A., Gomez, N., Hay, C., and Mitrovica, J.X. Sea Level Change in the Western James Bay Region of Subarctic Ontario: Emergent Land and Implications for Treaty No. 9. 69(1):99-107. 
Tyson, W., Lantz, T.C., and Ban, N.C. Cumulative Effects of Environmental Change on Culturally Significant Ecosystems in the Inuvialuit Settlement Region. 69(4):391-405.

Usher, P.J., and MacDonald, J. (Obituary) Gunther Abrahamson (1926-2016). 69(4):441-443.

Van Dijken, B. (See Ogden, A.E.)

Von Duyke, A.L., Stimmelmayr, R., Sheffield, G., Sformo, T., Suydam, R., Givens, G.H., and George, J.C. Prevalence and Abundance of Cyamid "Whale Lice" (Cyamus ceti) on Subsistence Harvested Bowhead Whales (Balaena mysticetus). 69(4):331-340.

Wenzel, G.W., Dolan, J., and Brown, C. Wild Resources, Harvest Data and Food Security in Nunavut's Qikiqtaaluk Region: A Diachronic Analysis. 69(2):147-159.

Wickler, S. (See Dove, C.J.)
Williams, L.P. (Book Review) Alaska's Skyboys: Cowboy Pilots and the Myth of the Last Frontier, by Katherine Johnson Ringsmuth. 69(2):206-207.

Wilson, R.E., Gust, J.R., Petersen, M.R., and Talbot, S.L. Spatial Genetic Structure of Long-Tailed Ducks (Clangula hyemalis) among Alaskan, Canadian, and Russian Breeding Populations. 69(1):65-78.

Wong, P.B.Y., and Murphy, R.W. Inuit Methods of Identifying Polar Bear Characteristics: Potential for Inuit Inclusion in Polar Bear Surveys. 69(4):406-420.

Woo, M.-K., and Thorne, R. Summer Low Flow Events in the Mackenzie River System. 69(3):286-304.

Younie, A.M. (Book Review) Kal'unek-From Karluk: Kodiak Alutiiq History and the Archaeology of the Karluk One Village Site, edited by Amy Steffian, Marnie Leist, Sven Haakanson, Jr., and Patrick Saltonstall. 69(1):112-113.

Younie, A.M., and Gillispie, T.E. Lithic Technology at Linda's Point, Healy Lake, Alaska. 69(1):79-98. 